\title{
Anti-inflammatory effects of levalbuterol-induced $11 \beta$-hydroxysteroid dehydrogenase type 1 activity in airway epithelial cells
}

\author{
Matthew J. Randall, Shannon F. Kostin, Edward J. Burgess, Laura R. Hoyt, Jennifer L. Ather, \\ Lennart K. Lundblad and Matthew E. Poynter*
}

Division of Pulmonary Disease and Critical Care Medicine, Department of Medicine, College of Medicine, The University of Vermont, Burlington, VT, USA

\section{Edited by:}

Abraham B. Roos, Karolinska

Institutet, Sweden

Reviewed by:

Abraham B. Roos, Karolinska

Insitutet, Sweden

Cecilia Karin Andersson, Imperial

College, UK

*Correspondence:

Matthew E. Poynter, Division of

Pulmonary Disease and Critical Care

Medicine, Department of Medicine,

College of Medicine, The University of

Vermont, 89 Beaumont Avenue,

Given Building E410A, Burlington, VT

05405, USA

e-mail: matthew.poynter@uvm.edu
Airway epithelial NF-kB activation is observed in asthmatic subjects and is a cause of airway inflammation in mouse models of allergic asthma. Combination therapy with inhaled shortacting $\beta_{2}$-agonists and corticosteroids significantly improves lung function and reduces inflammation in asthmatic subjects. Corticosteroids operate through a number of mechanisms to potently inhibit NF-kB activity. Since $\beta_{2}$-agonists can induce expression of $11 \beta-H S D 1$, which converts inactive 11-keto corticosteroids into active 11-hydroxy corticosteroids, thereby potentiating the effects of endogenous glucocorticoids, we examined whether this mechanism is involved in the inhibition of NF-KB activation induced by the $\beta$-agonist albuterol in airway epithelial cells. Treatment of transformed murine Club cells (MTCC) with (R)-albuterol (levalbuterol), but not with (S)- or a mixture of $(\mathrm{R}+\mathrm{S})$ - (racemic) albuterol, augmented mRNA expression of 11/-HSD1. MTCC were stably transfected with luciferase (luc) reporter constructs under transcriptional regulation by NF-kB (NF-kB/luc) or glucocorticoid response element (GRE/luc) consensus motifs. Stimulation of NF-кB/luc MTCC with lipopolysaccharide (LPS) or tumor necrosis factor- $\alpha$ (TNF $\alpha$ ) induced luc activity, which was inhibited by pretreatment with (R)-, but not (S)- or racemic albuterol. Furthermore, pretreatment of GRE/luc MTCC with (R)-, but not with (S)- or racemic albuterol, augmented 11-keto corticosteroid (cortisone) induced luc activity, which was diminished by the $11 \beta-H S D$ inhibitor glycyrrhetinic acid (18ß-GA), indicating that there was a conversion of inactive 11-keto to active 11-hydroxy corticosteroids. LPS- and TNF $\alpha$-induced NF-kB/luc activity was diminished in MTCC cells treated with a combination of cortisone and (R)albuterol, an effect that was inhibited by $18 \beta-G A$. Finally, pretreatment of MTCC cells with the combination of cortisone and (R)-albuterol diminished LPS- and TNF $\alpha$-induced pro-inflammatory cytokine production to an extent similar to that of dexamethasone. These results demonstrate that levalbuterol augments expression of $11 \beta-H S D 1$ in airway epithelial cells, reducing LPS-induced NF-kB transcriptional activity and pro-inflammatory cytokine production through the conversion of inactive 11-keto corticosteroids into the active 11-hydroxy form in this cell type.

Keywords: albuterol, anti-inflammatory, 11beta-hydroxysteroid dehydrogenase, glucocorticoid, epithelium

\section{INTRODUCTION}

Asthma affects over 300 million Americans, causing morbidity and mortality through an inability to breathe effectively (1). The pathogenesis of asthma is characterized by airway inflammation, airflow obstruction, and bronchial hyperresponsiveness (2). A classic anti-inflammatory medication used in the treatment of asthma and in animal models of the disease is corticosteorids such as the endogenous human glucocorticoid, hydrocortisone, and synthetic glucocorticoids, including prednisone, budesonide, fluticasone, and dexamethasone (3), the latter of which have greater and protracted activity profiles compared to the endogenous molecules. This comes with a cost; long-term and high-dose glucocorticoid treatment can have serious side-effects, including a general feeling of malaise (e.g., weight gain and bloating), immunosuppression, cataracts, dysphonia, growth retardation in children, and osteoporosis in adults (4).

Glucocorticoids inhibit inflammation through multiple mechanisms (5), an important one involving interference with NF- $\mathrm{kB}$, a pleiotropic transcription factor that is activated in response to inflammatory cytokines, mitogens, physical and oxidative stress, infection and microbial products, as well as allergens (6). NF- $\kappa \mathrm{B}$ regulates a number of responses in mammalian cells, including the expression of many pro-inflammatory cytokines and chemokines $(7,8)$. NF- $\mathrm{KB}$ is active in the airway epithelium of both asthmatic patients (9-12) and in mouse models of the disease (13), wherein it is a signal critical in evoking pulmonary inflammation (8). We have demonstrated that inhibition of NF- $\mathrm{KB}$ activity in the airway epithelium of mice is sufficient to diminish many of 
the inflammatory features of both an ovalbumin (14) and a house dust mite (15) model of asthma, while activation of airway epithelial NF- $\mathrm{B}$ exacerbates allergic airway disease (16) and enables allergic sensitization to an innocuous inhaled antigen (17).

The tissue levels of bioactive glucocorticoids are modulated by $11 \beta$-hydroxysteroid dehydrogenases (11 $\beta$-HSD), which interconvert corticosteroids between inactive and active states (18); only the active forms of corticosteroids are capable of interacting with the glucocorticoid receptor (GR). 11 $\beta$-HSD2 acts as a classical dehydrogenase by converting active 11-hydroxylated cortisol and corticosterone (in mice), into inactive 11-keto forms of cortisone and 11-dehydrocorticosterone, respectively $(19,20)$. 11 $\beta$-HSD1, on the other hand, acts predominantly as an oxidoreductase, converting inactive 11-keto to active 11-hydroxylated corticosteroids $(18,21,22)$. The activities of $11 \beta$-HSD enzymes at sites of glucocorticoid action, such as the airway epithelium, are essential for maintaining the balance between corticosteroid activity and inactivity, a process termed end-organ metabolism.

Another hallmark feature of asthma is hypersensitivity and hyperresponsiveness to bronchoconstricting stimuli, including inhalation of allergens, cold air, or methacholine. Agonists of the $\beta_{2}$ adrenergic receptor ( $\beta_{2}$-agonists) such as albuterol increase intracellular CAMP, activate protein kinase A, induce transcription of responsive genes, and trigger relaxation of airway smooth muscle $(23,24)$. Consequently, $\beta_{2}$-agonists are routinely employed as rescue medication for the treatment of acute asthma exacerbations (i.e., shortness of breath) (24). In addition, $\beta_{2}$-agonists may also be prescribed as a maintenance medication, oftentimes in combination with corticosteroids, to keep airways open and prevent acute exacerbations.

The short-acting $\beta_{2}$-agonist, albuterol, can be synthesized as two distinct enantiomers: (R)-(levalbuterol) and (S)-albuterol. A mixture of enantiomers, $(\mathrm{R}+\mathrm{S})$-albuterol (racemic albuterol) is less costly to synthesize and is the most commonly used form of the drug (25). Although it has been debated whether there are pharmacological advantages to one or the other albuterol enantiomers (26), it is appreciated that levalbuterol is the "active" form conveying the therapeutic effect of albuterol (27-29), whereas (S)-albuterol has 100 times less affinity for the $\beta_{2}$-receptor and may generate confounding effects $(30,31)$ or even function as an inhibitor for the effects of levalbuterol (32) when present in the racemic mixture.

Combination therapy with glucocorticoids and $\beta_{2}$-agonists addresses two seemingly distinct hallmarks of the disease. However, in addition to their bronchodilatory effects, $\beta_{2}$-agonists have anti-inflammatory effects on lung epithelium (33). The combination of corticosteroids and $\beta_{2}$-agonists has been observed to decrease asthma symptoms, increase overall lung function, and inhibit inflammatory mediator production by airway epithelial and other pulmonary cell types better than either medication alone (34), which suggests that there are synergistic effects of the combination.

As corticosteroids in combination with $\beta_{2}$-agonists generally provide asthma control $(34,35)$, yet protracted or systemic corticoid use can cause deleterious side-effects (4), the motivation for our study was to examine whether some of the anti-inflammatory effects of $\beta_{2}$-agonists are mediated through their capacity to modulate the bioactivity of endogenous corticosteroids in a cell type and through a signaling pathway relevant to asthma pathogenesis. It has been demonstrated that the $\beta$-agonist, salbutamol, induces $11 \beta$-HSD 1 oxidoreductase activity (conversion of inactive cortisone into active cortisol) in adipocytes (36). We explored in our studies whether a similar mechanism exists in airway epithelial cells, which express $\beta$-adrenergic receptors (37), and which can be exploited for therapeutic benefit in the treatment of asthma. Our long-term goal is to identify pathways that enable efficacious and affordable asthma control, without the systemic effects of oral corticosteroids.

\section{MATERIALS AND METHODS \\ CELL CULTURE AND TREATMENT}

Murine bronchiolar epithelial cells (MTCC, SV40 transformed Club cells) obtained from Dr. Francisco DeMayo (38) were cultured at $37^{\circ} \mathrm{C}$ in $95 \%$ humidified air containing $5 \% \mathrm{CO}_{2}$ using DMEM (Gibco, Grand Island, NY, USA) containing 10\% FBS (Cell Generation, Fort Collins, CO, USA), $2 \mathrm{mM} \mathrm{L-glutamine,} 50 \mathrm{U} / \mathrm{ml}$ penicillin, and $50 \mu \mathrm{g} / \mathrm{ml}$ streptomycin (Gibco). For experimentation, cells were seeded at 50,000 cells $/ \mathrm{cm}^{2}$ and grown to confluence. Cells were treated with $10^{-6} \mathrm{M}(\mathrm{R})-$, $(\mathrm{S})-$, racemic mixture of (R)- and (S)- albuterol (Sepracor, Marlborough, MA, USA), or $10 \mathrm{ng} / \mathrm{ml}$ TNF $\alpha$ (R\&D Systems, Minneapolis, MN, USA) for $24 \mathrm{~h}$ after which RNA was isolated. Post-albuterol exposure, cells were treated with $100 \mathrm{ng} / \mathrm{ml}$ lipopolysaccharide (LPS; InvivoGen, San Diego, CA, USA) or $10 \mathrm{ng} / \mathrm{ml} \mathrm{TNF} \alpha$ for $16 \mathrm{~h}$ after which cell lysates were prepared for analysis of luciferase (luc) activity and cell-free conditioned media were collected for measurement of cytokines. $18 \beta$-glycyrrhetinic acid, an inhibitor of $11 \beta$-HSD, and dexamethasone, a synthetic form of cortisol, were purchased from Sigma (St. Louis, MO, USA).

\section{GENE EXPRESSION}

Total RNA was extracted from MTCC cultured on 12-well plates using the PrepEase RNA isolation kit (USM Corp., Cleveland, $\mathrm{OH}, \mathrm{USA}$ ) and reverse transcribed to cDNA using the iScript kit (Bio-Rad, Hercules, CA, USA). Real-time quantitative RT-PCR was performed using iQ Supermix (Bio-Rad) and intron-spanning primers on a Bio-Rad Chromo4. Primers were designed for mouse Hsd11b1 (5' ${ }^{\prime}$ TTA TTG TCA AGG CGG GAA A5-3' and 5'-GGC GTC AAT TAT CCC AGA GA-3'), Hsd11b2 (5'-TCA TCA CCG GTT GTG ACA CT-3' and 5'-GGT ATG GCA TGT CTC CTG CT- $\left.3^{\prime}\right)$, and Gapdh (5'-ACG ACC CCT TCA TTG ACC TC-3' and $5^{\prime}$-TTC ACA CCC ACT ACA AAC AT- $\left.3^{\prime}\right)$. The levels of gene expression were normalized to Gapdh levels and relative expression was calculated according to the comparative cycle threshold $\left(\Delta \Delta \mathrm{C}_{\mathrm{T}}\right)$ method, as previously described (17).

\section{LUCIFERASE ASSAY}

MTCC were stably transfected with a mammalian expression vector containing an NF- $\kappa$ B-regulated luc reporter (Biomyx Technology, San Diego, CA, USA) or a glucocorticoid response element (GRE; from the mouse mammary tumor virus long terminal repeat) regulated luc reporter $[\mathrm{pHH}-\mathrm{luc}(39)$ from Nordeen, University of Colorado Health Sciences Center via Daynes, University of Utah) using lipofectamine (Life Technologies, Grand Island, 
NY, USA). Stable transfectants were selected using neomycin or hygromycin (Sigma). For quantitation of luc activity, equal quantities of cellular protein, quantitated by the Bradford method (Bio-Rad), were extracted following treatment and analyzed using a Berthold Lumat LB9501 luminometer and luciferin substrate, as previously described (13).

\section{CYTOKINE MEASUREMENT}

Bio-Plex (Bio-Rad, Hercules, CA, USA) kits were designed containing coupled polystyrene beads and antibodies recognizing mouse IL-1 $\beta$, IL-6, IL-12p40, IL-12p70, eotaxin, GM-CSF, GCSF, KC, MCP-1, MIP- $1 \alpha$, MIP- $1 \beta$, and RANTES. All assays were performed in duplicate according to manufacturer's instructions. Briefly, $50 \mu$ l of coupled beads were added to each well of a pre-wet 96-well microtiter plate with filter bottoms, washed twice using a Bio-Rad (Hercules, CA, USA) Bio-Plex Pro II wash station with the vacuum plate carrier, and $100 \mu \mathrm{l}$ of sample (cell-free conditioned media), standard, or assay buffer (background) was added to each well. The plates were covered, shaken vigorously for $1 \mathrm{~min}$ on an IKA (Wilmington, NC, USA) MTS 2/4 digital microtiter plate shaker and then moderately shaken for $4 \mathrm{~h}$ at room temperature. After washing, $25 \mu \mathrm{l}$ of biotinylated detection antibodies were added to each well for $1 \mathrm{~h}$ with shaking followed by addition of $50 \mu \mathrm{l}$ of streptavidin-PE to all wells for $30 \mathrm{~min}$ with shaking. The wells were washed and the beads were resuspended in $125 \mu \mathrm{l}$ sheath fluid and shaken to resuspend. Data were acquired at low PMT setting using the Bio-Rad Bio-Plex suspension array system and Bio-Plex Manager 6.0 software. Fluorescence intensity of the background was subtracted from the values for each sample and standard for each specific bead. Seven-point standard curves were generated from fourfold dilutions of standards provided in the Bio-Plex kits, which were analyzed using five-place logistic regression from standards within $95-105 \%$ of the expected values. Upper levels of quantitation and lower levels of quantitation were calculated by the Bio-Plex Manager 6.0 software. Reported concentrations are in picograms per milliliter of the cytokines that were induced by LPS and TNF $\alpha$ and were inhibited by dexamethasone (IL-6, GM-CSF, G-CSF, KC, MCP-1, MIP- $1 \alpha$, and RANTES).

\section{STATISTICAL CALCULATIONS}

Data are presented as mean \pm SEM and were analyzed by two-way ANOVA followed by inter-groups analysis by two-tailed unpaired $t$-test with Bonferroni correction for multiple comparisons using GraphPad Prism 6 (San Diego, CA, USA). A $p$ value $<0.05$ was considered statistically significant.

\section{RESULTS}

\section{R-ALBUTEROL INDUCES 11 $\beta$-HSD1 GENE EXPRESSION}

For our studies, we used a transformed non-ciliated murine airway epithelial cell line, MTCC (38). These cells, also referred to as Club cells, represent an abundant cell type lining the conducting airways of mice and humans, which are amongst those cells anatomically positioned in vivo such that they are exposed to inhaled bronchodilators and steroids (40). Furthermore, we have reported that murine Club cells are an important regulator of pro-inflammatory cytokine production through their capacity to activate the transcription factor NF- $\mathrm{B}(13-15,17)$. For the studies conducted herein, we first confirmed by Western blot that the MTCC, like the mouse lung, do indeed express the $\beta_{2}$-adrenergic receptor (data not shown). Although not as abundant on a per microgram protein basis as the whole lung, expression of $\beta_{2}$-adrenergic receptor protein suggested that these cells were well-suited to the investigation of the effects of albuterol on airway epithelium. We next investigated whether MTCC express mRNA for $11 \beta$ HSD isoforms, $11 \beta-H S D 1$, and $11 \beta-H S D 2$, and whether $11 \beta-H S D$ expression was affected by albuterol treatment. We exposed MTCC to $(\mathrm{R})$-albuterol, $(\mathrm{S})$-albuterol, or $(\mathrm{R}+\mathrm{S})$ albuterol at a number of doses and for a number of durations (data not shown) in order to establish relevant exposure regimens for our studies. When MTCC were exposed to $10^{-6} \mathrm{M}(\mathrm{R})$-albuterol for $24 \mathrm{~h}$ there was a significant increase in the expression of $11 \beta-H S D 1$ (Figure 1A).
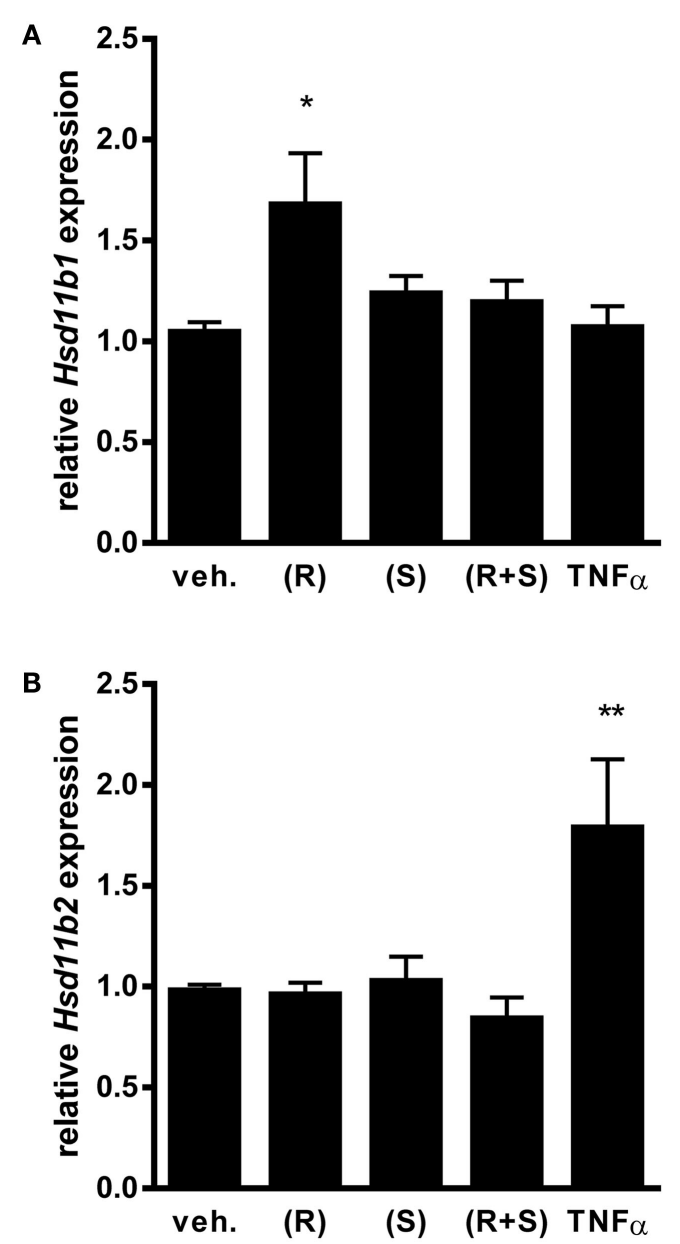

FIGURE 1 | Exposure to (R)-albuterol, but not (S)-albuterol or racemic $(\mathrm{R}+\mathrm{S})$-albuterol, induces mRNA expression of 11 $\beta$-HSD1, but not $11 \beta$-HSD2, in airway epithelial cells. MTCC were exposed to $10^{-6} \mathrm{M}$ $(\mathrm{R})$-albuterol $(\mathrm{R})$, (S)-albuterol $(\mathrm{S})$, racemic $(\mathrm{R}+\mathrm{S})$-albuterol, or $10 \mathrm{ng} / \mathrm{ml}$ TNF $\alpha$. Twenty-four hours later, RNA was isolated, cDNA was generated, and $11 \beta$-HSD1 (Hsd11b1), 11 $\beta$-HSD2 (Hsd11b2), and GAPDH (Gapdh) gene expression were analyzed by quantitative PCR. Relative expression of $11 \beta$-HSD1 (A) and $11 \beta$-HSD2 (B) were calculated. Data were pooled from three separate experiments. $n=6-9 /$ group; ${ }^{*} p \leq 0.05$ and ${ }^{*} p \leq 0.01$ compared to vehicle. 
However, neither $(\mathrm{S})$-albuterol nor $(\mathrm{R}+\mathrm{S})$-albuterol influenced $11 \beta-H S D 1$ mRNA expression. In addition, none of the albuterol enantiomers affected the expression of $11 \beta-H S D 2$ (Figure 1B). As a positive control, $24 \mathrm{~h}$ exposure to $10 \mathrm{ng} / \mathrm{ml}$ recombinant mouse $\mathrm{TNF} \alpha$ significantly increased $11 \beta-H S D 2$ expression. These results demonstrate that albuterol, in particular (R)-albuterol, selectively induces $11 \beta-H S D 1$ expression in airway epithelial cells.

\section{LPS- AND TNF $\alpha$-INDUCED NF- $\kappa B$ ACTIVITY IS DIMINISHED BY (R)-ALBUTEROL TREATMENT}

Since R-albuterol exposure significantly increased 11 $\beta$-HSD1 expression in MTCC, we investigated whether albuterol would diminish NF- $\kappa$ B activity induced by two prototypical agonists, LPS and TNF $\alpha$. LPS is an abundant environmental agonist of TLR4, a receptor important for cellular responses to several asthmarelevant allergens $(41,42)$. TNF $\alpha$ is elevated in allergic asthma and in mouse models of allergic airway disease, wherein it initiates and amplifies pulmonary inflammatory responses (43). Having established the half-maximal doses of these agonists, MTCC stably transfected with a NF- $\kappa \mathrm{B}$-dependent luc reporter gene were exposed to $100 \mathrm{ng} / \mathrm{ml} \mathrm{LPS}$ or $10 \mathrm{ng} / \mathrm{ml} \mathrm{TNF} \alpha$ in the absence or presence of $10^{-6} \mathrm{M}(\mathrm{R})$-albuterol, (S)-albuterol, or $(\mathrm{R}+\mathrm{S})$ albuterol. While LPS significantly induced NF-кB-luc activity, simultaneous exposure with albuterol did not diminish LPSinduced NF- $\kappa \mathrm{B}$ activity (data not shown). Similar results were measured when $10 \mathrm{ng} / \mathrm{ml}$ TNF $\alpha$ was substituted for LPS (data not shown). Although we had hypothesized that simultaneous treatment with albuterol would diminish LPS- or TNF $\alpha$-induced NF- $\kappa \mathrm{B}$ activation, we tested whether pretreatment with albuterol would be more effective. Therefore, MTCC were left untreated or were treated with $10^{-6} \mathrm{M}(\mathrm{R})-$, $(\mathrm{S})$-, or $(\mathrm{R}+\mathrm{S})$-albuterol for $24 \mathrm{~h}$. Cells were then treated with $100 \mathrm{ng} / \mathrm{ml} \mathrm{LPS} \mathrm{or} 10 \mathrm{ng} / \mathrm{ml}$ $\mathrm{TNF} \alpha$ for $16 \mathrm{~h}$ and analyzed for NF- $\kappa \mathrm{B}$ activity. While treatment with LPS (without or with albuterols) significantly increased NF- $\kappa$ B-dependent luc reporter activity, only pretreatment with $10^{-6} \mathrm{M}(\mathrm{R})$-albuterol significantly reduced LPS-induced NF- $\kappa \mathrm{B}$ activity (Figure 2A). Similarly, pretreatment with $10^{-6} \mathrm{M}(\mathrm{R})$ albuterol also significantly reduced TNF $\alpha$-induced NF- $\kappa$ B activity (Figure 2B).

\section{SUPPRESSION OF NF- $\mathrm{B}$ ACTIVITY BY (R)-ALBUTEROL IS DEPENDENT UPON 11 $\beta$-HSD1}

To elucidate whether the capacity of $(\mathrm{R})$-albuterol treatment to diminish NF- $\kappa \mathrm{B}$ activity was partially due to the activity of glucocorticoids, GRE-dependent luc reporter transfected MTCC were used. Since we had demonstrated that $24 \mathrm{~h}$ pre-exposure of MTCC to $(\mathrm{R})$-albuterol augmented $11 \beta$-HSD1 expression and diminished LPS- and TNF $\alpha$-induced NF- $\kappa$ B activity, GRE-luc MTCC were either left unexposed or exposed to $10^{-6} \mathrm{M}(\mathrm{R})$-albuterol for $24 \mathrm{~h}$. Post-albuterol exposure, $10^{-6} \mathrm{M}$ cortisone (with or without $10^{-6} \mathrm{M}$ of the $11 \beta$-HSD inhibitor glycyrrhetinic acid) was then administered to the cell culture medium and incubated for an additional $16 \mathrm{~h}$. As a positive control, GRE-luc MTCC were treated with $10^{-8} \mathrm{M}$ of the synthetic, 11-hydroxy (bioactive) glucocorticoid, dexamethasone for the entire $30 \mathrm{~h}$ of the experiment. Pretreatment with $(\mathrm{R})$-albuterol followed by exposure to cortisone modestly but significantly induced GRE-luc activity (Figure 3).
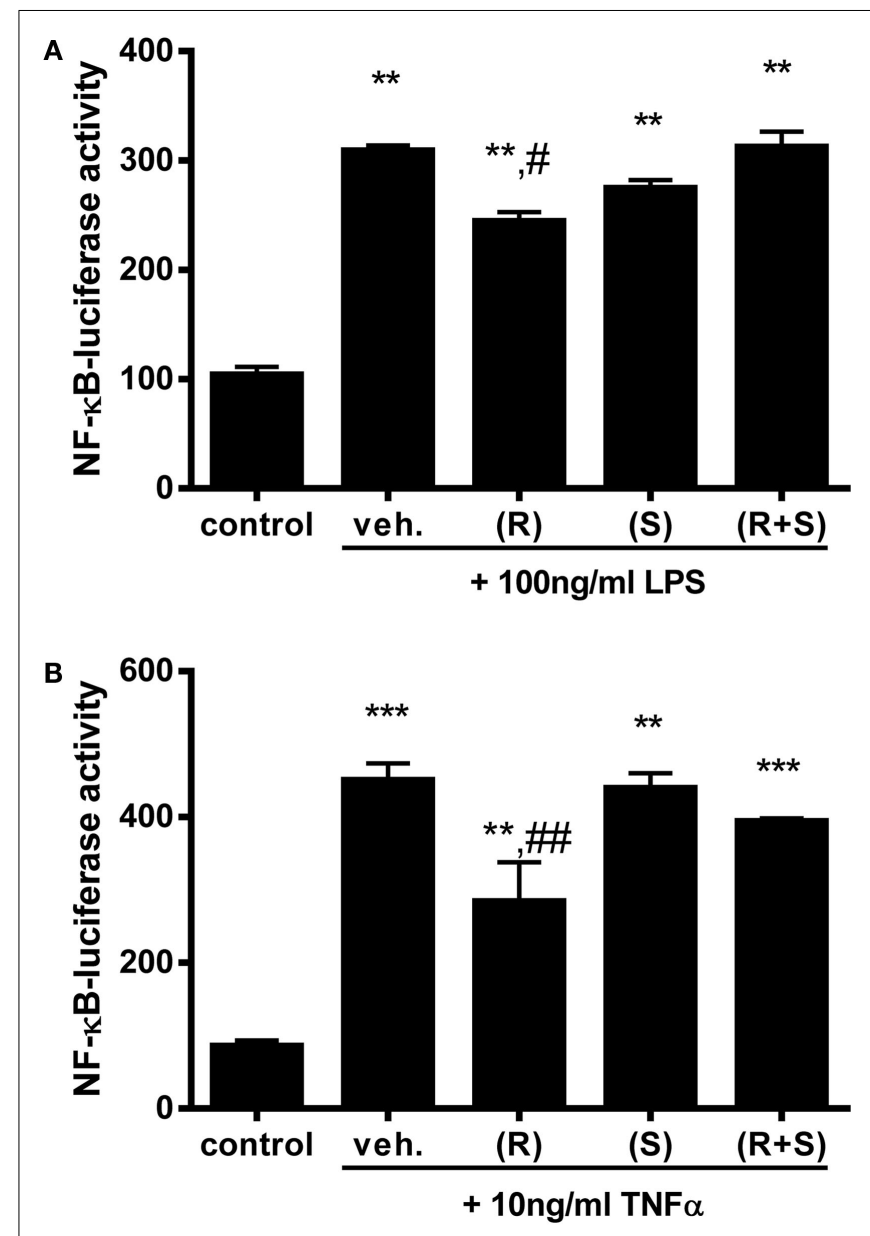

FIGURE 2 | Pre-exposure to (R)-albuterol reduces LPS- and TNF $\alpha$-induced NF- $\kappa$ B activity in airway epithelial cells. NF- $\kappa B$-luciferase MTCC were exposed to vehicle (veh.) or $10^{-6} \mathrm{M}(\mathrm{R})$-albuterol (R), (S)-albuterol (S), or ( $\mathrm{R}+\mathrm{S}$ )-albuterol for $24 \mathrm{~h}$. All cells except control were then exposed to $100 \mathrm{ng} / \mathrm{ml}$ LPS (A) or $10 \mathrm{ng} / \mathrm{mlTNF} \alpha$ (B). Sixteen hours later, cell lysates were prepared, luciferase activity was measured, and protein concentration was determined. $n=5-6 /$ group and the experiment was repeated twice; ${ }^{* *} p \leq 0.01$ compared to control, ${ }^{* *} p \leq 0.001$ compared to control, ${ }^{\#} p \leq 0.05$ compared to vehicle, ${ }^{\# \#} p \leq 0.01$ compared to vehicle.

The effect of (R)-albuterol combined with cortisone was dependent on the activity of $11 \beta$-HSD 1 , as the addition of $10^{-6} \mathrm{M}$ of the $11 \beta$-HSD inhibitor glycyrrhetinic acid significantly diminished GRE-luc activity.

Subsequently, we assessed the role of $11 \beta-\mathrm{HSD} 1$ in albuterol

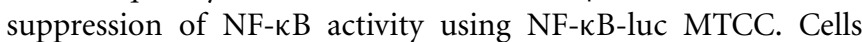
were exposed for $24 \mathrm{~h}$ to $10^{-6} \mathrm{M}$ cortisone alone or to $10^{-6} \mathrm{M}$ (R)-albuterol with or without $10^{-6} \mathrm{M}$ cortisone and $10^{-6} \mathrm{M}$ glycyrrhetinic acid. Following this exposure, cells were stimulated with $100 \mathrm{ng} / \mathrm{ml}$ LPS or $10 \mathrm{ng} / \mathrm{ml} \mathrm{TNF \alpha}$ for $16 \mathrm{~h}$ and NF-кBdependent luc activity was measured. As is shown in Figure 4A, only the combined pretreatment of (R)-albuterol and cortisone significantly, albeit modestly, decreased LPS-induced NF-кB-luc activation. Similarly, as is shown in Figure 4B, the combined pretreatment with $(\mathrm{R})$-albuterol and cortisone significantly, albeit 


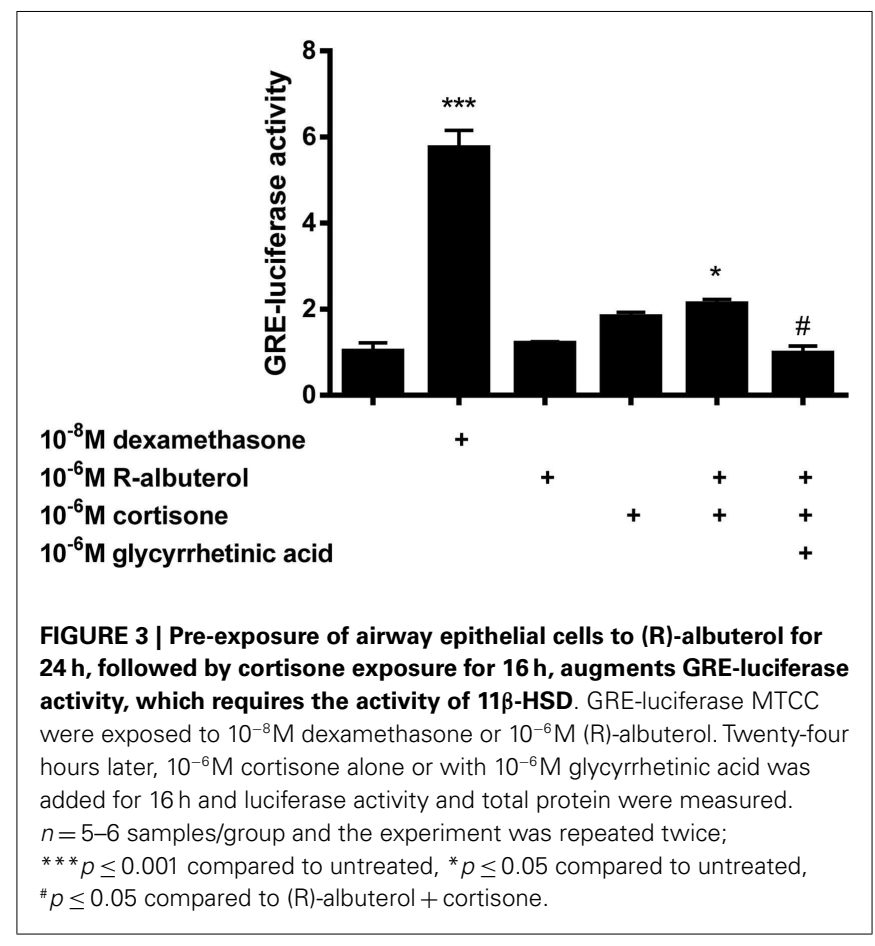

modestly, decreased TNF $\alpha$-induced NF- $\kappa$ B-luc activation. Pretreatment with the inactive glucocorticoid, cortisone, had no effect on LPS- or TNF $\alpha$-induced NF- $\kappa \mathrm{B}$-luc activity in the absence of (R)-albuterol. In the cases of both LPS and TNF $\alpha$ exposure, pretreatment with the $11 \beta$-HSD inhibitor, glycyrrhetinic acid, prevented much of the effect of combined pretreatment with (R)albuterol and cortisone, implicating the importance of $11 \beta$-HSD1 activity. These experiments demonstrate that only (R)-albuterol augmented 11-keto corticosteroid induced GRE-luc activation, indicating that there was a modest but statistically significant conversion of inactive 11-keto to active 11-hydroxy corticosteroids capable of inhibiting LPS- and TNF $\alpha$-induced NF- $\kappa$ B activity.

\section{(R)-ALBUTEROL SUPPRESSES PRODUCTION OF NF-KB-REGULATED CYTOKINES}

We have previously reported the critical contribution that NF$\kappa \mathrm{B}$ activation in non-ciliated airway epithelial cells (Club cells) has in mouse models of acute lung injury (44) and allergic airway disease (13-17), wherein these cells secrete cytokines that orchestrate innate and adaptive immune responses. Using MTCC cells as an in vitro model, we left the cells untreated or pretreated the cells for $24 \mathrm{~h}$ with $10^{-8} \mathrm{M}$ dexamethasone, $10^{-6} \mathrm{M}$ cortisone, $10^{-6} \mathrm{M}(\mathrm{R})$-albuterol, or a combination of $10^{-6} \mathrm{M}(\mathrm{R})$-albuterol and $10^{-6} \mathrm{M}$ cortisone. Cells were then stimulated with $100 \mathrm{ng} / \mathrm{ml}$ LPS or $10 \mathrm{ng} / \mathrm{ml} \mathrm{TNF} \alpha$ for $16 \mathrm{~h}$ and cytokines were measured from cell-free conditioned medium. As is shown in Figure 5A, only the combined pretreatment of (R)-albuterol and cortisone significantly decreased LPS-induced production of IL-6, GM-CSF, G-CSF, MCP-1, and MIP- $1 \alpha$. Similarly, the combined pretreatment with (R)-albuterol and cortisone significantly decreased TNF $\alpha$-induced production of IL-6, GM-CSF, KC, MCP-1, MIP- $1 \alpha$, and RANTES (Figure 5B). Notably, pretreatment with cortisone
A

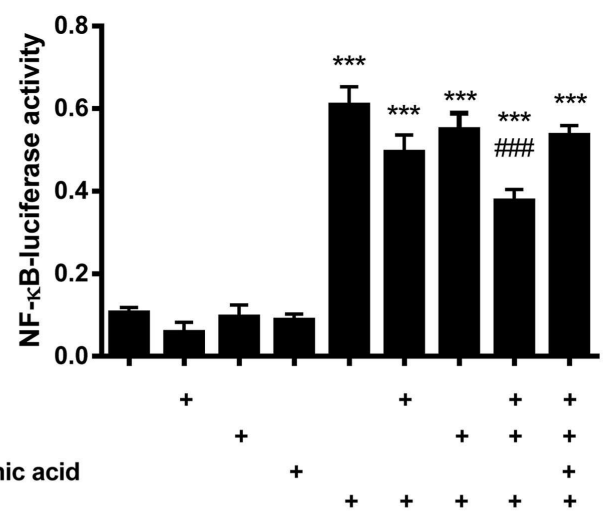

B

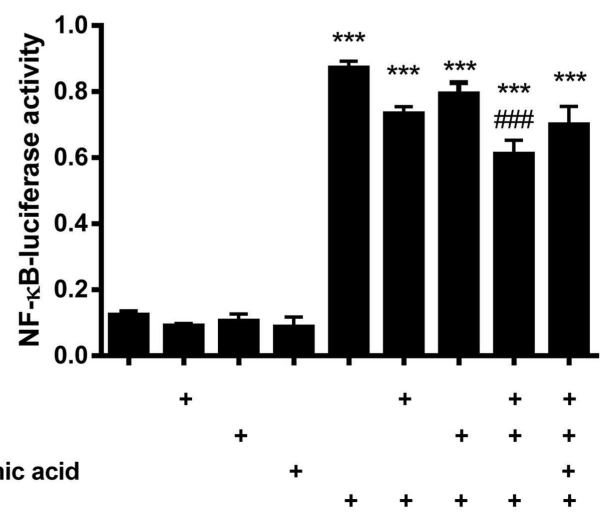

FIGURE 4 | Pre-exposure of MTCC to (R)-albuterol and cortisone for $24 \mathrm{~h}$, followed by exposure to LPS orTNF $\alpha$ for $16 \mathrm{~h}$, diminishes NF-kB-luciferase activity, which requires the activity of $11 \beta-H S D$ NF-kB-luciferase MTCC were exposed for $24 \mathrm{~h}$ to $10^{-6} \mathrm{M}$ cortisone alone or to $10^{-6} \mathrm{M}(\mathrm{R})$-albuterol with or without $10^{-6} \mathrm{M}$ cortisone and $10^{-6} \mathrm{M}$ glycyrrhetinic acid. Twenty-four hours later, $100 \mathrm{ng} / \mathrm{ml}$ LPS (A) or $10 \mathrm{ng} / \mathrm{ml}$ TNF $\alpha$ (B) were added to the cell culture medium. Cells were then lysed $16 \mathrm{~h}$ later using reporter lysis buffer. Luciferase activity and total protein were then measured. $n=4-6$ samples/group and the experiment was repeated twice; ${ }^{* * *} p \leq 0.001$ compared to untreated, ${ }^{\# \# \#} p \leq 0.001$ compared to LPS (A) or TNF $\alpha$ (B), ${ }^{*} p \leq 0.05$ compared to LPS (A) or TNF $\alpha$ (B).

alone had no effect on LPS- or TNF $\alpha$-induced cytokine production in the absence of (R)-albuterol. These experiments implicate $(\mathrm{R})$-albuterol-regulated $11 \beta$-HSD1 activity as a potentially important modulator of pro-inflammatory signaling and cytokine production in airway epithelial cells.

\section{DISCUSSION}

The combination therapy of corticosteroids and $\beta_{2}$-agonists has been typically demonstrated as an effective therapy for many patients with asthma and COPD. These drugs target airflow obstruction and airway inflammation, two of the most pressing features of these pulmonary diseases. $\beta_{2}$-adrenergic and GRs are expressed by many cells within the lung, including airway epithelium, one of the principle cell types exposed when these drugs are delivered by inhalation. While many of the cell signaling events activated following $\beta$-agonist or glucocorticoid exposure have been elucidated, there remains a gap in our understanding of how 


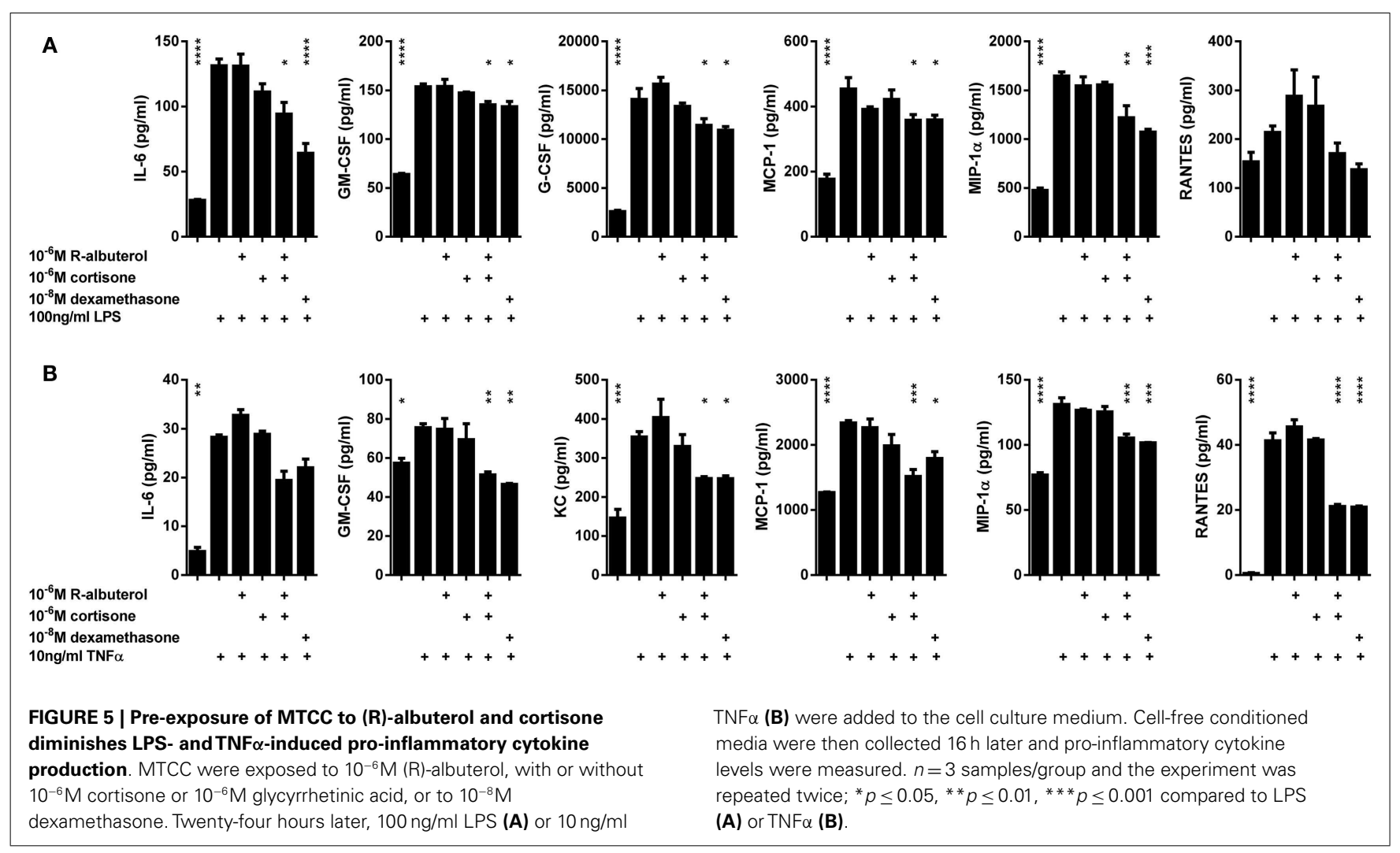

the two drugs may interact synergistically to provide better disease control than each alone. One possibility is that $\beta_{2}$-agonists induce changes in gene expression that allow for differential sensitivity to endogenous glucocorticoids. Thereby, higher local concentrations of bioactive glucocorticoids may be able to provide exceptional anti-inflammatory activity at the sites in which that activity is most needed, without the potentially deleterious side-effects that can be induced by systemic steroids. In support of this hypothesis, GR function has been reported to increase following $\beta_{2}$-agonist treatment (35).

$11 \beta$-HSD enzymes interconvert inactive circulating 11-keto glucocorticoids into bioactive 11-hydroxy steroids capable of interacting with the GR (45). We have demonstrated that (R)albuterol significantly reduces both LPS- and TNF $\alpha$-induced NF- $\kappa B$ activity while increasing GRE activation in an 11/HSD1 dependent manner, manifesting in lower levels of proinflammatory cytokine production from a transformed mouse airway epithelial cell line. In this study, we first compared levalbuterol to both (S)- and racemic albuterol, wherein we identified that levalbuterol moderately, but selectively, induces expression of $11 \beta-H S D 1$ but not $11 \beta-H S D 2$, whereas (S)- and racemic albuterol had no effect on either. The comparison of (R)-, (S)-, and $(\mathrm{R}+\mathrm{S})$-albuterol has been studied extensively in clinical or basic research, with several outcomes supporting the use of (R)- over (S)-albuterol $(28,46-48)$. In this vein, there is evidence to suggest that the (R)-enantiomer is the bioactive component and that the S-enantiomer may even have detrimental effects (49). Although others have stated that there is an opposite effect or no difference between enantiomer treatments $(26,50)$, one could argue that the complexity of asthma as a disease could potentiate such differences in treatment efficacy. It is not clear why in our studies neither the $(\mathrm{S})$ - nor racemic $(\mathrm{R}+\mathrm{S})$-albuterol induced $11 \beta-\mathrm{HSD} 1$ expression. One potential explanation for the lack of response from albuterols containing the (S)-enantiomer lies in the higher binding affinity of (R)-albuterol to the $\beta_{2}$-adrenergic receptor (32). While our studies did not enable us to explore this possibility in our airway epithelial cell model system, the data clearly demonstrate the ability of only (R)-albuterol to elicit anti-inflammatory effects.

We further addressed whether the anti-inflammatory property of levalbuterol requires endogenous glucocorticoid signaling. Previous studies that have attempted to distinguish a route through which albuterol enhances corticosteroid sensitivity primarily focus on downstream signaling of the GR following glucocorticoid exposure and neglect to consider that albuterol may modulate levels of localized endogenous corticosteroid. A study by Usmani et al. identified that long-acting $\beta_{2}$-agonists could increase nuclear localization of the GR and increase DNA binding of GR enhancing glucocorticoid function (51). Our data are complimentary in this regard for levalbuterol, a short-acting $\beta_{2}$-agonist, since we observed an enhanced GRE-luc activity following levalbuterol treatment, although only in the presence of cortisone. Conversely, Eickelberg et al. have suggested that long-acting $\beta_{2}$-agonists can activate the GR independently of corticosteroid binding (52) whereas Loven et al. suggest a GR independent mechanism (53). Albeit, we attribute the levalbuterol-mediated GRE-luc activity observed to GR activation via the conversion of cortisone to cortisol by $11 \beta-H S D 1$ given that we can inhibit the GRE activity by

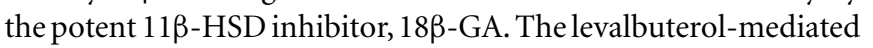


suppression of NF- $\kappa \mathrm{B}$ activity following TNF $\alpha$ or LPS stimulation was also partially prevented following the administration of $18 \beta$-GA indicating a role for $11 \beta$-HSD 1 in the anti-inflammatory function of levalbuterol. Furthermore, the capacity of $18 \beta$-GA to partially block the inhibitory effects of (R)-albuterol on GREand NF-кB-dependent luc activity specifically implicates necessity for the oxidoreductase (11-keto to 11-hydroxy conversion) activity of $11 \beta$-HSD1 for albuterol-mediated suppression of NF$\kappa \mathrm{B}$. By extension, the requirement for $(\mathrm{R})$-albuterol pretreatment and the addition of cortisone for the diminution of LPS- and $\mathrm{TNF} \alpha$-induced pro-inflammatory cytokine production implies that active glucocorticoids mediate this effect.

Whether the effects of (R)-albuterol observed in vitro would translate into biologically significant reductions in inflammatory cytokine or chemokine production in vivo remain unknown. In addition, it is uncertain whether airway epithelium is the most relevant cell type in which to study $11 \beta$-HSD activities in response to $\beta_{2}$-agonists. While the MTCC cell line was utilized for our studies based on the important functions we have attributed to NF- $\kappa \mathrm{B}$ activity in Club cells of mice (13-17, 44), MTCC retain only a limited number of the characteristics of in vivo Club cells (38) and are not representative of the more abundant ciliated airway epithelial cells lining the conducting airways of humans. Furthermore, our cell model system did not involve culturing at an air-liquid interface, which is more representative of the in vivo state of differentiated airway epithelium. Our studies should be extended to primary cells from healthy mice and those with allergic airway disease, as well as to healthy human subjects and those with different asthma endotypes (54). In addition to epithelia, many other types of cells present in the inflamed airway, including lymphocytes and macrophages that are pathogenic in asthma and COPD, express $11 \beta$-HSD1 $(55,56)$ and may be modulated in their activity by $\beta_{2}$-agonists $(57,58)$. Nevertheless, the modest reductions we observed in vitro are of a similar magnitude to what has been recently reported from an elegant in vivo study using a mouse model of allergic asthma in which (R)-albuterol modestly diminished inflammation and NF- $\mathrm{B}$ activity (58). Finally, whether the observed effects of (R)-albuterol would also be mimicked or even enhanced by a long-acting $\beta_{2}$-agonists, such as $(\mathrm{R}, \mathrm{R})$-formoterol, which do diminish inflammatory cytokine production by human airway epithelial cells in vitro (59), remains an intriguing question. Certainly, there is the potential that longterm augmentation of airway epithelial $11 \beta$-HSD 1 oxidoreductase activity could provide endogenous glucocorticoids with powerful and localized anti-inflammatory activities. Our finding that pretreatment of epithelial cells with (R)-albuterol was required to elicit inhibitory effects on LPS- or TNF $\alpha$-induced activation suggests that maintenance therapy [with (R)-albuterol] may be more beneficial than as-needed treatment.

Taken together, our results define a mechanism by which levalbuterol may suppress airway inflammation (Figure 6). Translation of our in vitro findings suggests that $\beta_{2}$-agonist induced enhancement of $11 \beta$-HSD1 oxidoreductase activity in the airway epithelium of asthmatic patients has the potential to increase

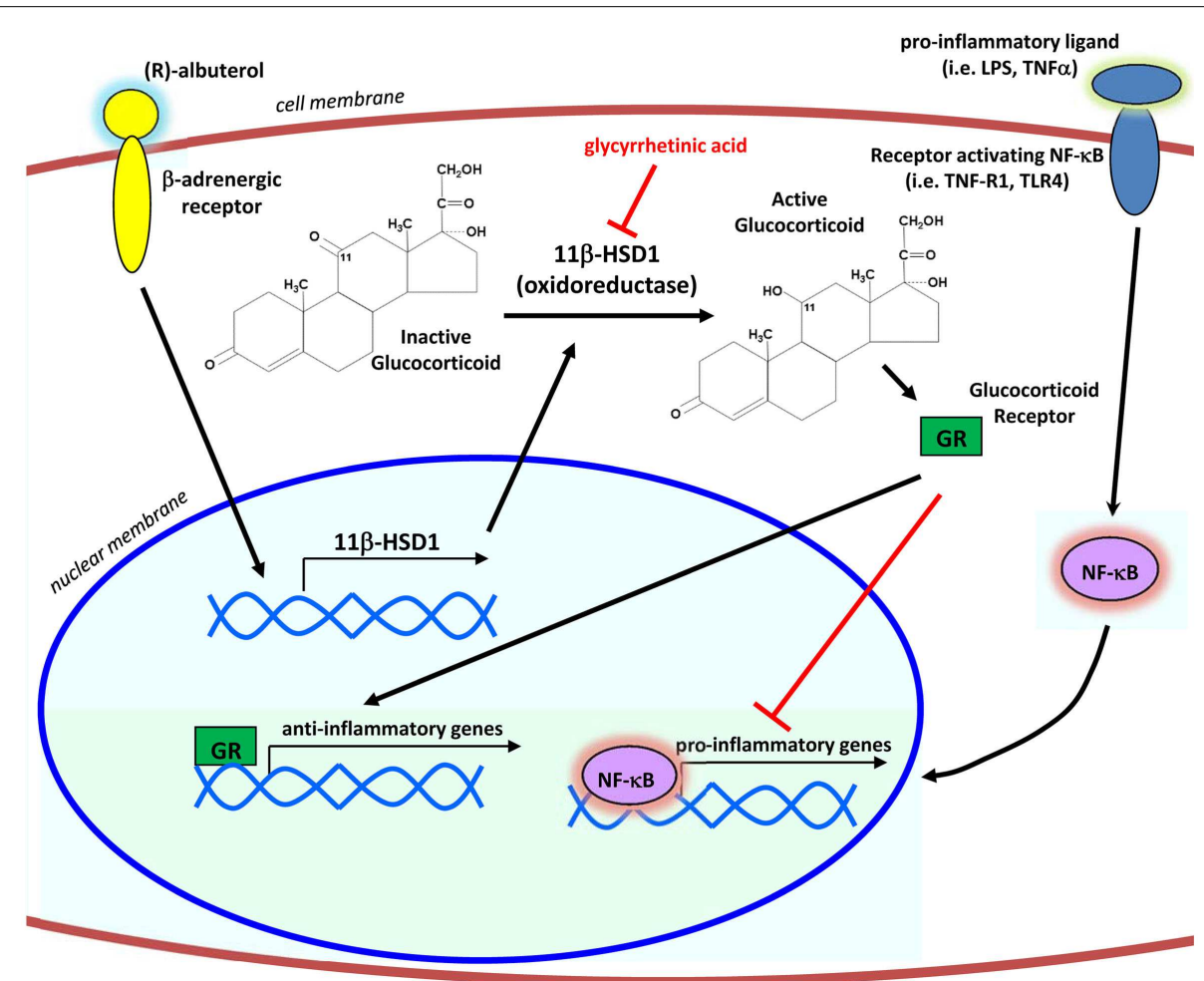

FIGURE 6 | Proposed mechanism of action. By signaling through the $\beta 2$-adrenergic receptor, (R)-albuterol transcriptionally upregulates the mRNA expression and oxidoreductase activity of $11 \beta-H S D 1$ in airway epithelial cells, thereby potentiating the anti-inflammatory effects of endogenous glucocorticoids to inhibit activity of the pro-inflammatory transcription factor NF-кB. 
the metabolic activation of their endogenous cortisol and suppress baseline inflammatory responses, in particular those involving transcriptional control by NF- $\mathrm{B}$. Through the activation of endogenous corticosteroids selectively in the affected lung epithelium, levalbuterol and potentially other $\beta_{2}$-agonists could be used as a tool enabling clinicians to circumvent the use of long-term or systemic corticosteroid therapies for the treatment of inflammatory airway diseases.

\section{ACKNOWLEDGMENTS}

We thank Christine C. Jones, Ph.D. and Emily Milbank (UVM) for technical assistance, and Leesa Barone, Ph.D. and Rebecca Persinger, Ph.D. (Sepracor, Inc.) for numerous helpful discussions. This work was supported by a grant from Sepracor, Inc., Marlborough, MA, USA.

\section{REFERENCES}

1. Akinbami LJ, Moorman JE, Bailey C, Zahran HS, King M, Johnson CA, et al. Trends in asthma prevalence, health care use, and mortality in the United States, 2001-2010. NCHS Data Brief (2012) 94:1-8.

2. National Asthma E, Prevention P. Expert panel report 3 (EPR-3): guidelines for the diagnosis and management of asthma-summary report 2007. J Allergy Clin Immunol (2007) 120:S94-138. doi:10.1016/j.jaci.2007.09.029

3. Ito K, Getting SJ, Charron CE. Mode of glucocorticoid actions in airway disease. ScientificWorldJournal (2006) 6:1750-69. doi:10.1100/tsw.2006.274

4. Barnes PJ. Glucocorticosteroids: current and future directions. Br J Pharmacol (2011) 163:29-43. doi:10.1111/j.1476-5381.2010.01199.x

5. De Bosscher K, Vanden Berghe W, Haegeman G. Mechanisms of antiinflammatory action and of immunosuppression by glucocorticoids: negative interference of activated glucocorticoid receptor with transcription factors. $J$ Neuroimmunol (2000) 109:16-22. doi:10.1016/S0165-5728(00)00297-6

6. Kagoshima M, Ito K, Cosio B, Adcock IM. Glucocorticoid suppression of nuclear factor-kappa B: a role for histone modifications. Biochem Soc Trans (2003) 31:60-5. doi:10.1042/BST0310060

7. Ckless K, Hodgkins SR, Ather JL, Martin R, Poynter ME. Epithelial, dendritic, and CD4(+) $\mathrm{T}$ cell regulation of and by reactive oxygen and nitrogen species in allergic sensitization. Biochim Biophys Acta (2011) 1810:1025-34. doi:10.1016/j.bbagen.2011.03.005

8. Poynter ME. Airway epithelial regulation of allergic sensitization in asthma. Pulm Pharmacol Ther (2012) 25:438-46. doi:10.1016/j.pupt.2012.04.005

9. Hart LA, Krishnan VL, Adcock IM, Barnes PJ, Chung KF. Activation and localization of transcription factor, nuclear factor-kappaB, in asthma. Am J Respir Crit Care Med (1998) 158:1585-92. doi:10.1164/ajrccm.158.5.9706116

10. Lee JI, Burckart GJ. Nuclear factor kappa B: important transcription factor and therapeutic target. J Clin Pharmacol (1998) 38:981-93. doi:10.1177/ 009127009803801101

11. Hart L, Lim S, Adcock I, Barnes PJ, Chung KF. Effects of inhaled corticosteroid therapy on expression and DNA-binding activity of nuclear factor kappaB in asthma. Am J Respir Crit Care Med (2000) 161:224-31. doi:10.1164/ajrccm.161. 1.9809019

12. Hamilton LM, Davies DE, Wilson SJ, Kimber I, Dearman RJ, Holgate ST. The bronchial epithelium in asthma - much more than a passive barrier. Monaldi Arch Chest Dis (2001) 56:48-54.

13. Poynter ME, Irvin CG, Janssen-Heininger YM. Rapid activation of nuclear factor-kappaB in airway epithelium in a murine model of allergic airway inflammation. Am J Pathol (2002) 160:1325-34. doi:10.1016/S0002-9440(10) 62559-X

14. Poynter ME, Cloots R, Van Woerkom T, Butnor KJ, Vacek P, Taatjes DJ, et al. NFkappa $\mathrm{B}$ activation in airways modulates allergic inflammation but not hyperresponsiveness. J Immunol (2004) 173:7003-9. doi:10.4049/jimmunol.173.11. 7003

15. Tully JE, Hoffman SM, Lahue KG, Nolin JD, Anathy V, Lundblad LK, et al. Epithelial NF-kappaB orchestrates house dust mite-induced airway inflammation, hyperresponsiveness, and fibrotic remodeling. J Immunol (2013) 191:5811-21. doi:10.4049/jimmunol.1301329
16. Pantano C, Ather JL, Alcorn JF, Poynter ME, Brown AL, Guala AS, et al. Nuclear factor-kappaB activation in airway epithelium induces inflammation and hyperresponsiveness. Am J Respir Crit Care Med (2008) 177:959-69. doi:10.1164/rccm.200707-1096OC

17. Ather JL, Hodgkins SR, Janssen-Heininger YM, Poynter ME. Airway epithelial NF-kappaB activation promotes allergic sensitization to an innocuous inhaled antigen. Am J Respir Cell Mol Biol (2011) 44:631-8. doi:10.1165/rcmb.20100106OC

18. Seckl JR, Walker BR. Minireview: 11beta-hydroxysteroid dehydrogenase type 1 - a tissue-specific amplifier of glucocorticoid action. Endocrinology (2001) 142:1371-6. doi:10.1210/endo.142.4.8114

19. Suzuki T, Sasano H, Suzuki S, Hirasawa G, Takeyama J, Muramatsu Y, et al. 11Beta-hydroxysteroid dehydrogenase type 2 in human lung: possible regulator of mineralocorticoid action. J Clin Endocrinol Metab (1998) 83:4022-5. doi:10.1210/jcem.83.11.5227

20. Orsida BE, Krozowski ZS, Walters EH. Clinical relevance of airway 11betahydroxysteroid dehydrogenase type II enzyme in asthma. Am J Respir Crit Care Med (2002) 165:1010-4. doi:10.1164/ajrccm.165.7.2105003

21. Tomlinson JW, Walker EA, Bujalska IJ, Draper N, Lavery GG, Cooper MS, et al. 11Beta-hydroxysteroid dehydrogenase type 1: a tissue-specific regulator of glucocorticoid response. Endocr Rev (2004) 25:831-66. doi:10.1210/er.20030031

22. Morgan SA, McCabe EL, Gathercole LL, Hassan-Smith ZK, Larner DP, Bujalska IJ, et al. 11Beta-HSD1 is the major regulator of the tissue-specific effects of circulating glucocorticoid excess. Proc Natl Acad Sci U S A (2014) 111:E2482-91. doi:10.1073/pnas.1323681111

23. Liggett SB. Update on current concepts of the molecular basis of beta2adrenergic receptor signaling. J Allergy Clin Immunol (2002) 110:S223-7. doi:10.1067/mai.2002.129945

24. Cazzola M, Page CP, Rogliani P, Matera MG. Beta2-agonist therapy in lung disease. Am J Respir Crit Care Med (2013) 187:690-6. doi:10.1164/rccm.2012091739PP

25. Page CP, Morley J. Contrasting properties of albuterol stereoisomers. J Allergy Clin Immunol (1999) 104:S31-41. doi:10.1016/S0091-6749(99)70271-X

26. Jat KR, Khairwa A. Levalbuterol versus albuterol for acute asthma: a systematic review and meta-analysis. Pulm Pharmacol Ther (2013) 26:239-48. doi:10.1016/j.pupt.2012.11.003

27. Keir S, Page C, Spina D. Bronchial hyperresponsiveness induced by chronic treatment with albuterol: role of sensory nerves. J Allergy Clin Immunol (2002) 110:388-94. doi:10.1067/mai.2002.126661

28. Nowak RM, Emerman CL, Schaefer K, Disantostefano RL, Vaickus L, Roach JM. Levalbuterol compared with racemic albuterol in the treatment of acute asthma: results of a pilot study. Am J Emerg Med (2004) 22:29-36. doi:10.1016/j.ajem. 2003.11.001

29. Lundblad LK, Rinaldi LM, Poynter ME, Riesenfeld EP, Wu M, Aimi S, et al. Detrimental effects of albuterol on airway responsiveness requires airway inflammation and is independent of beta-receptor affinity in murine models of asthma. Respir Res (2011) 12:27. doi:10.1186/1465-9921-12-27

30. Cho SH, Hartleroad JY, Oh CK. (S)-albuterol increases the production of histamine and IL-4 in mast cells. Int Arch Allergy Immunol (2001) 124:478-84. doi:10.1159/000053783

31. Agrawal DK, Ariyarathna K, Kelbe PW. (S)-albuterol activates pro-constrictory and pro-inflammatory pathways in human bronchial smooth muscle cells. $J$ Allergy Clin Immunol (2004) 113:503-10. doi:10.1016/j.jaci.2003.12.039

32. Penn RB, Frielle T, McCullough JR, Aberg G, Benovic JL. Comparison of R-, S-, and RS-albuterol interaction with human beta 1- and beta 2-adrenergic receptors. Clin Rev Allergy Immunol (1996) 14:37-45. doi:10.1007/BF02772201

33. Chorley BN, Li Y, Fang S, Park JA, Adler KB. (R)-albuterol elicits antiinflammatory effects in human airway epithelial cells via iNOS. Am J Respir Cell Mol Biol (2006) 34:119-27. doi:10.1165/rcmb.2005-0338OC

34. Knox AJ. The scientific rationale of combining inhaled glucocorticoids and long acting beta 2 adrenoceptor agonists. Curr Pharm Des (2002) 8:1863-9. doi:10.2174/1381612023393774

35. Barnes PJ. Scientific rationale for inhaled combination therapy with longacting beta2-agonists and corticosteroids. Eur Respir J (2002) 19:182-91. doi:10.1183/09031936.02.00283202

36. Friedberg M, Zoumakis E, Hiroi N, Bader T, Chrousos GP, Hochberg Z. Modulation of 11 beta-hydroxysteroid dehydrogenase type 1 in mature human 
subcutaneous adipocytes by hypothalamic messengers. J Clin Endocrinol Metab (2003) 88:385-93. doi:10.1210/jc.2002-020510

37. Salathe M. Effects of beta-agonists on airway epithelial cells. J Allergy Clin Immunol (2002) 110:S275-81. doi:10.1067/mai.2002.129412

38. Magdaleno SM, Wang G, Jackson KJ, Ray MK, Welty S, Costa RH, et al. Interferon-gamma regulation of Clara cell gene expression: in vivo and in vitro. Am J Physiol (1997) 272:L1142-51.

39. Nordeen SK, Suh BJ, Kuhnel B, Hutchison CA III. Structural determinants of a glucocorticoid receptor recognition element. Mol Endocrinol (1990) 4:1866-73. doi:10.1210/mend-4-12-1866

40. Proud D, Leigh R. Epithelial cells and airway diseases. Immunol Rev (2011) 242:186-204. doi:10.1111/j.1600-065X.2011.01033.x

41. Hammad H, Chieppa M, Perros F, Willart MA, Germain RN, Lambrecht BN. House dust mite allergen induces asthma via toll-like receptor 4 triggering of airway structural cells. Nat Med (2009) 15:410-6. doi:10.1038/nm.1946

42. Trompette A, Divanovic S, Visintin A, Blanchard C, Hegde RS, Madan R, et al. Allergenicity resulting from functional mimicry of a toll-like receptor complex protein. Nature (2009) 457:585-8. doi:10.1038/nature07548

43. Matera MG, Calzetta L, Cazzola M. TNF-alpha inhibitors in asthma and COPD: we must not throw the baby out with the bath water. Pulm Pharmacol Ther (2010) 23:121-8. doi:10.1016/j.pupt.2009.10.007

44. Ather JL, Alcorn JF, Brown AL, Guala AS, Suratt BT, Janssen-Heininger YM, et al. Distinct functions of airway epithelial nuclear factor-kappaB activity regulate nitrogen dioxide-induced acute lung injury. Am J Respir Cell Mol Biol (2010) 43:443-51. doi:10.1165/rcmb.2008-0416OC

45. Tomlinson JW, Stewart PM. Cortisol metabolism and the role of 11 betahydroxysteroid dehydrogenase. Best Pract Res Clin Endocrinol Metab (2001) 15:61-78. doi:10.1053/beem.2000.0119

46. Berger WE. Levalbuterol: pharmacologic properties and use in the treatment of pediatric and adult asthma. Ann Allergy Asthma Immunol (2003) 90:583-91. doi:10.1016/S1081-1206(10)61859-5

47. Carl JC, Myers TR, Kirchner HL, Kercsmar CM. Comparison of racemic albuterol and levalbuterol for treatment of acute asthma. J Pediatr (2003) 143:731-6. doi:10.1067/S0022-3476(03)00493-1

48. Nowak R, Emerman C, Hanrahan JP, Parsey MV, Hanania NA, Claus R, et al. A comparison of levalbuterol with racemic albuterol in the treatment of acute severe asthma exacerbations in adults. Am J Emerg Med (2006) 24:259-67. doi:10.1016/j.ajem.2006.01.027

49. Ameredes BT, Calhoun WJ. (R)-albuterol for asthma: pro [a.k.a. (S)-albuterol for asthma: con]. Am J Respir Crit Care Med (2006) 174:965-9. doi:10.1164/ rccm.2606001

50. Wilkinson M, Bulloch B, Garcia-Filion P, Keahey L. Efficacy of racemic albuterol versus levalbuterol used as a continuous nebulization for the treatment of acute asthma exacerbations: a randomized, double-blind, clinical trial. J Asthma (2011) 48:188-93. doi:10.3109/02770903.2011.554939

51. Usmani OS, Ito K, Maneechotesuwan K, Ito M, Johnson M, Barnes PJ, et al. Glucocorticoid receptor nuclear translocation in airway cells after inhaled combination therapy. Am J Respir Crit Care Med (2005) 172:704-12. doi:10.1164/ rccm.200408-1041OC
52. Eickelberg O, Roth M, Lorx R, Bruce V, Rudiger J, Johnson M, et al. Ligandindependent activation of the glucocorticoid receptor by beta2-adrenergic receptor agonists in primary human lung fibroblasts and vascular smooth muscle cells. J Biol Chem (1999) 274:1005-10. doi:10.1074/jbc.274.2.1005

53. Loven J, Svitacheva N, Jerre A, Miller-Larsson A, Korn SH. Anti-inflammatory activity of beta2-agonists in primary lung epithelial cells is independent of glucocorticoid receptor. Eur Respir J (2007) 30:848-56. doi:10.1183/09031936. 00129606

54. Martin RA, Hodgkins SR, Dixon AE, Poynter ME. Aligning mouse models of asthma to human endotypes of disease. Respirology (2014) 19:823-33. doi:10.1111/resp. 12315

55. Zhang TY, Ding X, Daynes RA. The expression of 11 beta-hydroxysteroid dehydrogenase type I by lymphocytes provides a novel means for intracrine regulation of glucocorticoid activities. J Immunol (2005) 174:879-89. doi:10.4049/ jimmunol.174.2.879

56. Zhang TY, Daynes RA. Macrophages from 11beta-hydroxysteroid dehydrogenase type 1-deficient mice exhibit an increased sensitivity to lipopolysaccharide stimulation due to TGF-beta-mediated up-regulation of SHIP1 expression. $J$ Immunol (2007) 179:6325-35. doi:10.4049/jimmunol.179.9.6325

57. Beusenberg FD, Adolfs MJ, Van Schaik A, Van Amsterdam JG, Bonta IL. Antigen challenge modifies the cyclic AMP response of inflammatory mediators and beta-adrenergic drugs in alveolar macrophages. Eur J Pharmacol (1989) 174:33-41. doi:10.1016/0014-2999(89)90870-4

58. Ferrada MA, Gordon EL, Jen KY, He HZ, Lu X, Barone LM, et al. (R)-albuterol decreases immune responses: role of activated T cells. Respir Res (2008) 9:3. doi:10.1186/1465-9921-9-3

59. Chiu JC, Hsu JY, Fu LS, Chu JJ, Chi CS. Comparison of the effects of two longacting beta2-agonists on cytokine secretion by human airway epithelial cells. $J$ Microbiol Immunol Infect (2007) 40:388-94.

Conflict of Interest Statement: The authors declare that the research was conducted in the absence of any commercial or financial relationships that could be construed as a potential conflict of interest.

Received: 31 October 2014; accepted: 18 December 2014; published online: 12 January 2015.

Citation: Randall MJ, Kostin SF, Burgess EJ, Hoyt LR, Ather JL, Lundblad LK and Poynter ME (2015) Anti-inflammatory effects of levalbuterol-induced 11 $\beta$ hydroxysteroid dehydrogenase type 1 activity in airway epithelial cells. Front. Endocrinol. 5:236. doi: 10.3389/fendo.2014.00236

This article was submitted to Molecular and Structural Endocrinology, a section of the journal Frontiers in Endocrinology.

Copyright $\odot 2015$ Randall, Kostin, Burgess, Hoyt, Ather, Lundblad and Poynter. This is an open-access article distributed under the terms of the Creative Commons Attribution License (CC BY). The use, distribution or reproduction in other forums is permitted, provided the original author $(s)$ or licensor are credited and that the original publication in this journal is cited, in accordance with accepted academic practice. No use, distribution or reproduction is permitted which does not comply with these terms. 